\title{
Post-dispersal seed predation in the hedgerows of agroecosystems in southern Chile
}

\section{Depredación post-dispersión de semillas en los cercos naturales de los agroecosistemas del sur de Chile}

\author{
Alberto G. Gantz ${ }^{1, *}$ \& Carlos E. Valdivia ${ }^{2}$ \\ 1'Laboratorio de Ecología, Departamento de Ciencias Biológicas y Biodiversidad, Universidad de Los Lagos, Av. Fuchslocher 1305, Osorno, Chile. \\ 2Laboratorio de Vida Silvestre, Departamento de Ciencias Biológicas y Biodiversidad, Universidad de Los Lagos, Av. Fuchslocher 1305, Osorno, Chile. \\ *E-mail: agantz@ulagos.cl
}

\begin{abstract}
Agricultural ecosystems host a large variety of organisms that can contribute to weed control through seed consumption. However, seed consumption rates in the agroecosystems of southern Chile are virtually unknown. We experimentally evaluate oat seed consumption by birds, rodents and invertebrates, in hedgerows dominated by trees, shrubs and grasses. Seed biomass consumed was not affected by the dominant vegetation present in the hedgerows, but did vary according to the seed consuming animal group. The principal seed consumers were rodents, followed by invertebrates and birds, the latter only appearing to be significant in shrub-dominated habitats. In addition, we observed the exotic slug Deroceras reticulatum consuming seeds in $62 \%$ of the experimental stations. Additional studies addressing the spatial-temporal dynamics of interactions between granivores and weed seeds are required to confirm the potential controlling and regulating function of rodents on weeds in the agricultural ecosystems of southern Chile.
\end{abstract}

Keywords: agricultural systems, consumption, granivory, hedgerows, seed.

\section{RESUMEN}

Los ecosistemas agrícolas albergan gran variedad de organismos que pueden contribuir al control de malezas a través del consumo de semillas. Sin embargo, la tasa de consumo de semillas en agroecosistemas del sur de Chile es desconocido. Evaluamos experimentalmente el consumo de semillas de avena por aves, roedores e invertebrados en cercos vivos dominados por árboles, arbustos y pastos. La biomasa de semillas consumida no fue afectada por la vegetación dominante presente en los cercos vivos, pero varió de acuerdo al grupo de animales consumidores de semillas. Los principales consumidores de semillas fueron los roedores, seguidos por las babosas y por las aves; estas últimas solo parecen ser significativas en habitats dominados por arbustos. Además, observamos la presencia de la babosa exotica Deroceras reticulatum consumiendo semillas en el $62 \%$ de las estaciones experimentales. Se requieren estudios adicionales sobre la dinámica espacio-temporal de las interacciones entre los granívoros y las semillas de malezas para confirmar la potencial función controladora y reguladora de los roedores sobre las malezas presentes en los ecosistemas agrícolas del sur de Chile.

Palabras clave: cercos naturales, consumo, granivoría, semillas, sistemas agrícolas. 


\section{INTRODUCTION}

Agricultural ecosystems host a wide variety of organisms, both native and exotic (Moonen et al. 2008). This biological diversity is intrinsically linked to different ecological functions, such as the consumption and dispersal of fruits and seeds by frugivorous and granivorous animals (Sekercioglu 2007; Fischer et al. 2011; Sekercioglu 2012; Schäckermann et al. 2015). Granivores are generally mammals, birds, and invertebrates, such as insects and mollusks, which feed (entirely or partially) on seeds and fruits (Hulme \& Beckman 2002; Wheelan et al. 2008). These animals are frequently considered plant antagonists because they kill the embryos contained in the seeds consumed (Hulme \& Backman 2002). Nevertheless, granivores can also, albeit less frequently, become mutualists, if the seeds consumed are dispersed effectively, which will depend on the plant and animals characteristics (Van der Wall 2010).

This combination of negative and positive granivore effects on seed survival and dispersal can modify plant community composition, structure and function (Muñoz \& Cavieres 2006; Vaz Ferreira et al. 2011; Warzecha \& Parker 2014). For this reason, granivores are important ecosystem service providers (Sekercioglu 2012). In fact, granivores can significantly limit the establishment of exotic plants that would otherwise invade agricultural ecosystems (Cardina et al. 1996; Westerman et al. 2003a; Vas Ferreira et al. 2011; Birthisel 2013). An example of this can be found in the Netherland agricultural fields, where weed seed predation by granivores is equivalent in magnitude to mechanical methods of control (Westerman et al. 2003a). Nevertheless, the granivore regulatory function has been questioned by some authors, who state that their effects on plant recruitment are negligible, even under high seed removal conditions (Hulme 2002; Worthy et al. 2006; Vaz Ferreira et al. 2011; Warzecha \& Parker 2014).

In addition to farming and management practices, agricultural landscape structure (e.g. presence of trees, shrubs, etc.), can affect granivore richness and abundance and, as a result, the ecosystem services they provide (Westerman et al. 2003a, 2003b; Birthisel 2013; Schäckermann et al. 2015). Animal traits can also determine their success as ecosystem service providers (Sekercioglu 2012). Thus, agricultural landscapes with a higher proportion of trees and shrubs could provide more shelter for larger granivores, such as birds and mammals, than habitats dominated by grasses, where small granivores, for example invertebrates, could be favored (Birthisel 2013).

In Chile, invertebrates, birds and, to a lesser extent, rodents, are the major seed consumers in diverse habitats such as semidesert scrubland, the Andean steppe and deciduous forests (Muñoz \& Arroyo 2002; Donoso et al. 2004; Kelt et al. 2004; Muñoz \& Cavieres 2006). Consequently, we would also expect birds and invertebrates, followed by rodents, to be the main granivores in the agricultural ecosystems of southern Chile. Furthermore, the reduced tree and shrub coverage in these environments usually triggers a decrease in bird and mammal diversity, including granivores (Sieving et al. 1996; Kelt 2004; Díaz et al. 2005; Castellón \& Sieving 2005). Accordingly, we also predict that seed consumption would be greater in environments that include trees and shrubs, than in those dominated by grasses. The general objective of our study is to evaluate granivory in agricultural environments, specifically in roadside locations (i.e. hedgerows) of southern Chile, using the exotic gramineae Avena sativa seeds. We evaluated roadsides because they are the habitual mode of entry of exotic species invading croplands and thus are where weeds must be controlled (van der Ree et al. 2015). Specifically, we evaluated the consumption of oat seeds by birds, rodents and invertebrates in hedgerows dominated by trees, shrubs or grasses.

\section{MATERIALS AND METHODS}

\section{SITE AND SPECIES STUDIED}

We conducted field work during the austral autumn, between March and April, 2017, along roadside hedgerows located in the province of Osorno, Los Lagos Region, Chile (between $40^{\circ} 39^{\prime} 20^{\prime \prime} \mathrm{S}-73^{\circ} 11^{\prime} 55^{\prime \prime} \mathrm{W}$ and $40^{\circ} 46^{\prime} 34^{\prime \prime} \mathrm{S}-7^{\circ} 08^{\prime} 25^{\prime \prime} \mathrm{W}$ ). During this period, exotic weed seed production in agricultural zones in southern Chilean agricultural zones is greatest (Matthei 1995). These habitats are structurally heterogeneous, although sectors dominated by trees, shrubs and annual grasses are distinguishable, generally located adjacent to pastures used for livestock forage (Gantz, personal observation).

The oat (Avena sativa $L$.) is a gramineae introduced into Chile by German settlers at the end of the XIX century, reintroduced from 1927 onwards, in its distinct commercial varieties (Beratto 2000). At present, it grows wild between the Maule (ca. $34^{\circ} \mathrm{S}$ ) and Magallanes (ca $54^{\circ} \mathrm{S}$ ) regions, and has a significant effect on agricultural activities (Matthei 1995).

Granivory. We conducted our study following previous protocols (Holmes \& Froud-Williams 2005; Birthisel 2013). We set up twenty nine experimental stations adjacent to hedgerows in a ca. $51.3 \mathrm{~km}^{2}$ study area. The stations were established in lineal habitats, dominated by trees $(n=10)$, shrubs $(n=10)$ and pastures $(n=9)$ (Fig. 1). To ensure sample independence, mean distance between each experimental station was $753.8 \pm 111.7$ $\mathrm{m}( \pm 1 \mathrm{SE})$. We set up three experimental arenas at every station, each containing $30 \mathrm{~g}$ dry oat seeds, enabling direct comparison with other studies on seed predation in different environments. Prior to the field work, we dried seeds at $60^{\circ} \mathrm{C}$ for $24 \mathrm{~h}$ in a Memmert oven to obtain a constant weight and kill the embryos, 
thus avoiding even more dissemination of this exotic species. Once dried, we offered the seeds to granivores on sifted sand placed in a plastic plate $20 \mathrm{~cm}$ diameter, $1 \mathrm{~cm}$ depth. In each of the stations, we separated the three experimental plates by a distance of $3 \mathrm{~m}$ in order to evaluate seed removal rates by three consumer groups: i) invertebrates, ii) invertebrates and rodents, and iii) invertebrates, rodents and seed-eating birds. In the case of invertebrates, we excluded larger predators (i.e. rodents and seed eating birds) from the seed arena by placing metallic mesh over the plates $(0.7 \mathrm{~cm}$ mesh opening), in the form of a $22 \mathrm{~cm}$ diameter, $10 \mathrm{~cm}$ high dome. To determine invertebrate and rodent seed removal rates, we placed the same metallic mesh dome over the plates in the second experimental arena and inserted a $50 \mathrm{~cm}$ long, $7 \mathrm{~cm}$ diameter PVC tube, open at one end, inside the dome (Kelt et al. 2004). This design prevented avian access, while permitting access to small and medium-sized rodents (Kelt et al. 2004). To evaluate
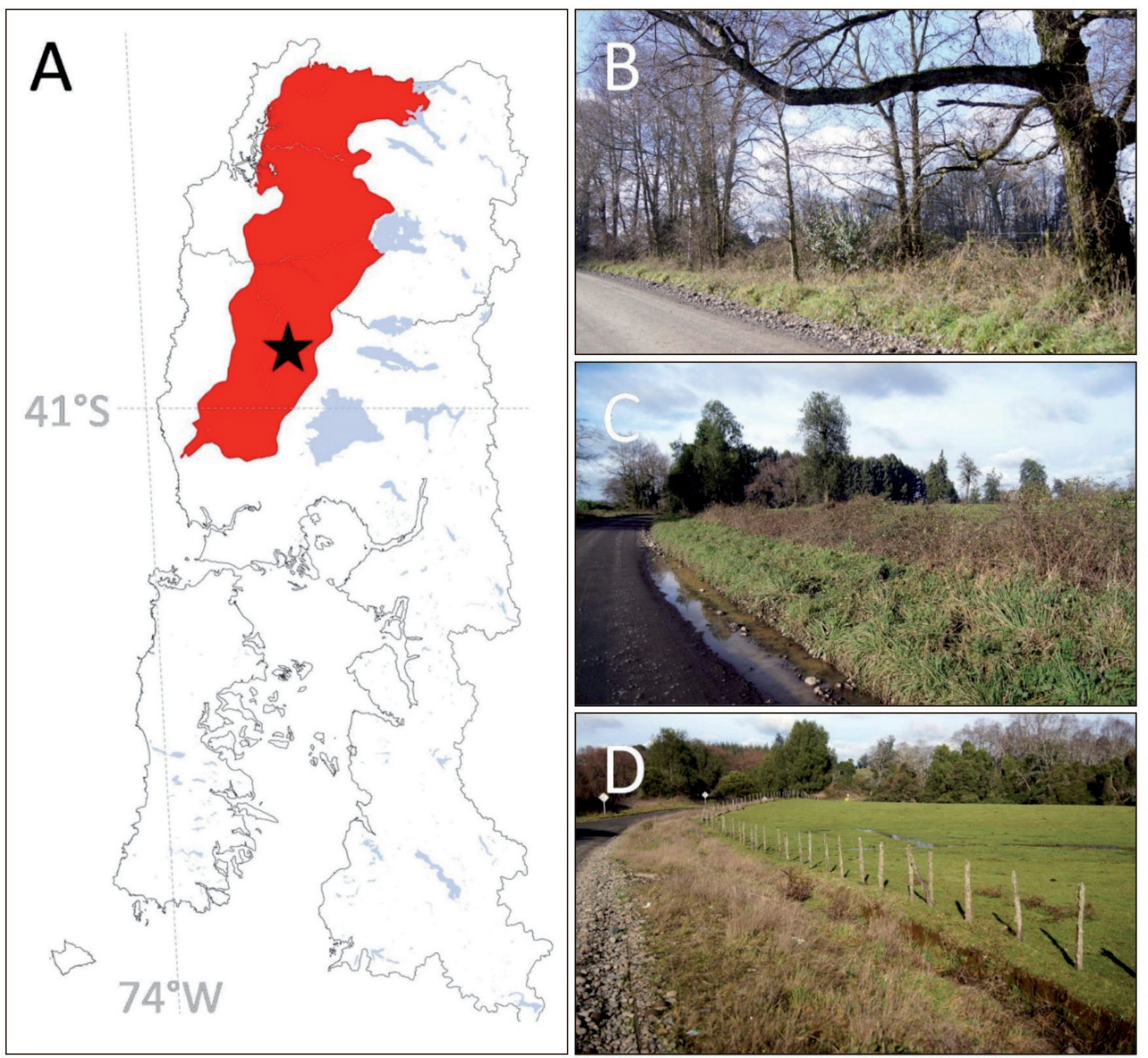

Figure 1. Los Ríos and Los Lagos regions, Chile, where the temperate mixed deciduous forest of Nothofagus obliqua and Laurelia sempervirens grows (highlighted red (A). Remnants of this forest usually persists along the roadsides, forming live fences, mostly comprising by N. obliqua (B), shrubs, such as Rubus ulmifolius (C) or, only by herbaceous weeds (D). The location of the study site is indicated with a star. / En Chile, en la Región de Los Ríos y de Los Lagos, crece el bosque decíduo templado de Nothofagus obliqua y Laurelia sempervirens (destacados en rojo en A). Restos de este bosque persisten en los bordes de caminos, fomando cercos vivos, principalmente formados por N. oblicua (B), por arbustos como Rubus ulmifolius (C) o, solo por malezas herbáceas (D). El área de studio está indicada con una estrella. 
seed removal rate by invertebrates, rodents and seed- eating birds in the third experimental arena, we, simply placed the seeds in the sand-filled plates, without any exclusion mechanism, enabling unrestricted access by all three animal groups. We fixed all the plates and metallic mesh dome to the ground using 4 inch nails, to avoid removal by predators. We exposed all treatments to predation over a $24 \mathrm{~h}$ period (set up at 10:00 and collected at 10:00-12:00 the following day), in the absence of precipitations and strong winds to avoid environmental bias. After the $24 \mathrm{~h}$ period, we collected the remaining seeds in each experimental arena and transported them to the laboratory where they were dried at $60^{\circ} \mathrm{C}$ for $24 \mathrm{~h}$, and subsequently weighed on a digital balance (0.01g accuracy). We estimated seed biomass removal rate in each habitat for each group of granivores, based on the difference between initial and the final dry weight.

\section{Statistical ANALYsIS}

To evaluate the effects of dominant plants in the hedgerow vegetation and variations in the granivore groups (i.e. independent variables) on the seed biomass removal rate (i.e. dependent variable), a main effect ANOVA (Analysis of Variance) was applied, using each experimental station as a replicate. We used the Statistica 10.0 statistical package (StatSoft Inc., Tulsa, Oklahoma, USA) for all analyses.

\section{RESULTS}

Seed biomass consumed was not significantly affected by the dominant vegetation in the hedgerows, but did vary according to the seed-consuming animal group (effect of dominant vegetation: $F_{(2 ; 82)}=2.08 ; p=0.132$; effect of granivore type: $\left.F_{(2 ; 82)}=14.56 ; p<0.001\right)$. Thus, we did not record significant differences in seed consumption between habitats dominated by trees and shrubs (Tukey test: $p=0.161$ ), trees and grasses $(p=0.989)$ and shrubs and grasses $(p=0.247)$. In these habitats, invertebrates presented a significantly lower consumption rate than the invertebrate and rodent group $(p=$ 0.001 ) and the group including invertebrates, rodents and seed eating birds $(p<0.001)$. However, there were no significant differences between consumption by invertebrates and rodents and invertebrates, rodents and seed-eating birds combined ( $p=$ 0.287 ). Thus, the main seed consumers were rodent, followed by invertebrates and finally seed-eating birds, the latter only being significant in habitats dominated by shrubs (Fig. 2). In fact, we observed rodent, but not bird, droppings in all experimental arenas. Furthermore, although our study did not focus on the seed consumer identity, we observed the exotic slugs Deroceras reticulatum (Limacidae) consuming Avena sativa seeds in 18 of the 29 experimental arenas.

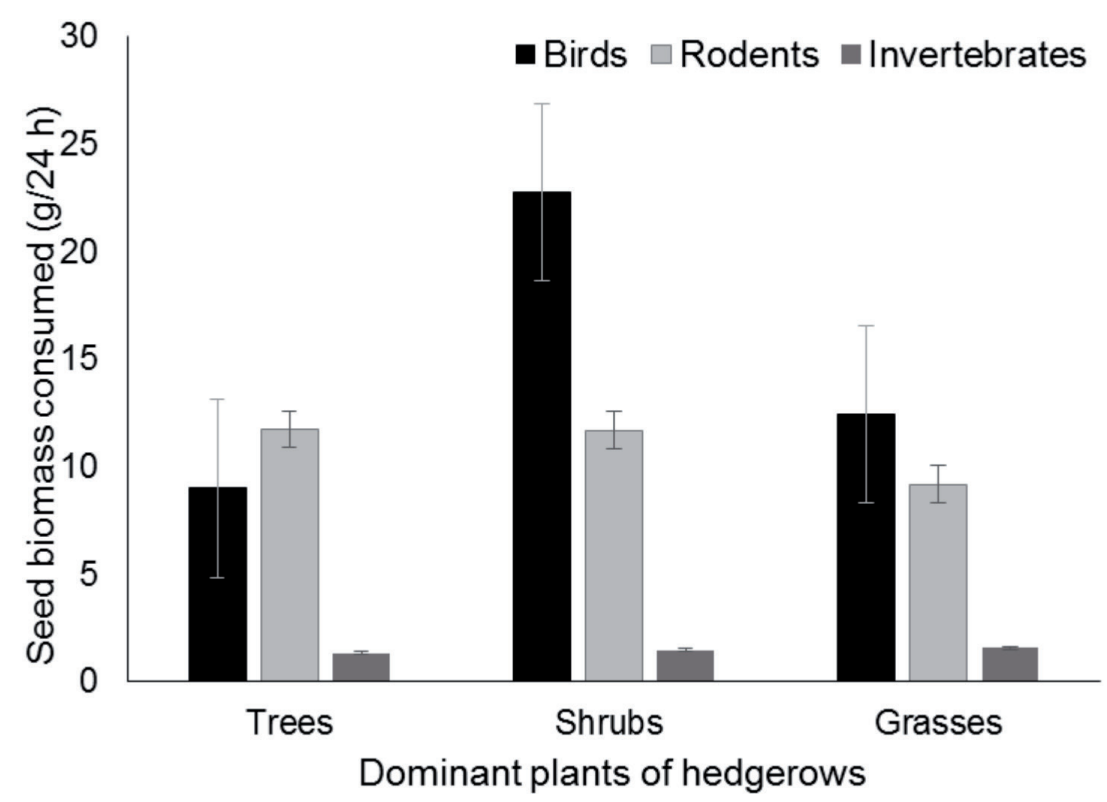

Figure 2. Avena sativa consumption rates (i.e. grams of dry biomass over $24 \mathrm{~h}$ ) by invertebrates, rodents and granivorous birds, according to dominant vegetation type (i.e. trees, shrubs or grasses) in an agricultural ecosystem of southern Chile. Means are indicated \pm 1SE. / Tasa de consumo de Avena sativa (i.e. gramos de biomasa seca en $24 \mathrm{~h}$ ) por invertebrados, roedores y aves granívoras de acuerdo al tipo de vegetación dominante (i.e. árboles, arbustos y hierbas), en un ecosistema agrícola del sur de Chile. Las medias son indicadas $\pm 1 \mathrm{ES}$. 


\section{DISCUSSION}

Contrary to our expectations, rodents were the main seed predators in hedgerows during autumn, followed by slugs; seed eating birds were less significant. Similarly, there were no significant differences between habitat types. These results are similar to granivory patterns reported in North America, where rodents and ants are the main seed consumers (Kelt et al. 2004). However, they differ from the findings of other studies on semi-arid ecosystems of northern Chile that identify seedeating birds as the dominant granivores. They also contrast with other reports from Andean highland ecosystems in the central zone of Chile and reports in scrubland environments in central and southern Argentina, where insects are the principal seed consumers (Folgarait \& Sala 2002; Muñóz \& Arroyo 2002; Kelt et al. 2004; Muñoz \& Cavieres 2006).

Seed consumption by seed eating birds was limited, in spite of the high abundance of granivorous and omnivorous birds present in the hedgerows (Silva-Rodríguez et al. 2008). We believe that the greater availability of seeds with more attractive characteristics than oats, altered bird consumption preferences and could account for the scarce bird predation observed (Westerman et al. 2003b; Warzecha \& Parker 2014). In addition, because the hedgerows are frequently used by numerous predators, predation risk could induce granivorous birds to consume seeds at a distance from the linear habitat vegetation and not adjacent to it, where our experiments were installed (Cresswell et al. 2011).

Rodent presented greatest seed consumption, probably due to the hedgerow vegetation structure which generally attracts numerous granivorous rodents and provides abundant food and shelter (Carvalho de Castro \& van den Berg 2013; Zuria \& Gates 2013). In southern Chile, the native olivaceous field mouse Abrothrix olivaceous and the long-tailed rice mouse Oligorizomys longicaudatus, together with the European rat Ratus ratus, are the most abundant rodents in hedgerows during the summer and early autumn, particularly those composed of the blackberry (Rubus ulmifolius), gramineae and other weeds (Barrera \& Murúa 2015). This vegetation structure provides greater foliage cover, leaf litter presence and gramineae abundance, factors which favor the presence of these rodents (Barrera \& Murrúa 2015). In fact, the greatest consumption of seeds by rodents reported in this study occurred in those hedgerows that were structurally and physionomically similar to those described by Barrera \& Murúa (2015). This suggests that the same microhabitat factors (i.e. coverage and food availability) accounted for greater rodent abundance and, consequently, greater seed removal in the hedgerows in our study area. In fact, the $77 \%$ of seeds consumed by rodents ( $23 \mathrm{~g}$ of a total of $30 \mathrm{~g}$ ) reported in our study exceeds the 2 to $56 \%$ range reported in other similar studies (Holmes \& Froud-Williams 2005; Worthy et al. 2006; Navontoft et al. 2009).

While the regulatory role of granivores is still controversial (e.g. Vaz Ferreira et al. 2011; Warzecha \& Parker 2014), some evidence suggests that they reduce the number of annual seeds and limit the establishment and dispersal of weed seeds in agricultural systems (e.g. Cardina et al. 1996; Westerman et al. 2003a; Navntoft et al. 2009; Vas Ferreira et al. 2011; Birthisel 2013). In fact, seed losses over $50 \%$ are considered sufficient to reduce weed density (Westerman et al. 2003a; Booman et al. 2009; Navntoft et al. 2009). Although we did not evaluate the regulatory function of seed predators, rodent consumption of $77 \%$ of total available seed biomass indicates that rodents could limit weed expansion in hedgerows. Furthermore, if we consider that seed removal intensity depend on seed exposure time, the high consumption over brief periods reported in our study would suggest that cumulative seed consumption by rats or mice could be even greater (Muñoz \& Arroyo 2002; Warzecha \& Parker 2014). In addition, although no previous reports relating to Deroceras reticulatum granivory in Chile are available, this gastropod is a known seed predator in other parts of the world and probably acts synergistically with rodents. This suggest that both species potentially play an important regulatory role, restricting the establishment and number of seeds in the agricultural systems studied.

Further studies addressing the spatial-temporal dynamics of interactions between granivorous and weed seeds are required to confirm the potential controlling and regulatory function of rodents and exotic slugs on weeds in the hedgerows associated with agricultural systems in southern Chile.

\section{ACKNOWLEDGEMENT}

We are grateful to Susan Angus for translating the manuscript and to the anonymous reviewers for their valuable comments and contributions that significantly improved this paper.

\section{REFERENCES}

Barrera, K., Murua, R. 2015. Nuevo desafío en salud pública: Presencia de reservorios de Anta, Oligoryzomys longicaudatus and Rattus spp., en áreas de borde en praderas del sur de Chile. Sustainability, Agriculture, Food and Environmental Research 3: 33-46.

Birthisel, S.K. 2013. Sources of variability in agronomic seed weed predation: Time, space, habitat, and hyperpredation. Doctorate Electronic Thesis and Dissertations. Paper 2023. University of Maine, USA.

Cardina, J., Norquay, H.M., Stinner, B.R., McCartney, D.A. 1996. Post-dispersal predation of Velvetleaf (Abutilon 
theophrastis) seeds. Weed Science 44: 534-539.

Carvalho de Castro, G., Van den Berg, E. 2013. Structure and conservation value of high-diversity hedgerows in southern Brazil. Biodiversity \& Conservation 22: 20412056.

Castellón, T.D., Sieving, K.E. 2005. An experimental test of matrix permeability and corridor use by an endemic understory bird. Conservation Biology 20: 135-145.

Cresswell, W., Lind, J., Quinn, J.L. 2010. Predator-hunting success and prey vulnerability: quantifying the spatial scale over which lethal and non-lethal effects of predation occur. Journal of Animal Ecology 79: 556-562.

Cristianini, A.V., Galetti, M. 2007. Toward reliable estimates of seed removal by small mammals and birds in the Neotropics. Brazilian Journal of Biology 67: 203-208.

Díaz, I.A., Armesto, J.J., Reid, S., Sieving, K.E., Willson, M.F. 2005. Linking forest structure and composition: avian diversity in successional forests of Chiloé Island, Chile. Biological Conservation 123: 91-101.

Donoso, D., Grez, A.A., Simonetti, J.A. 2004. Effect of forest fragmentation on the granivory of differently-sized seeds. Biological Conservation 115: 63-70.

Fisher, C., Thies, C., Tscharntke, T. 2011. Mixed effect of landscape complexity and farming practice on weed seed removal. Perspective in Plant Ecology 13: 297-303.

Holmes, R.J., Froud-Williams, R.J. 2005. Post-dispersal seed weed predation by avian and non-avian predators. Agriculture, Ecosystems \& Environment 105: 23-27.

Howe, H.F., Brown, J.S. 1999. Effects of birds and rodents on synthetic tall grass communities. Ecology 80: 1776-1781.

Hulme, P. E. 2002. Seed-eaters: Seed dispersal, destruction and demography. In: Levey, D.J., Silva, W.R., Galetti, M. (Eds.) Seed dispersal and frugivory: ecology, evolution and conservation: 257-273 pp. CABI Publishing, Wallingford, UK.

Hulme, P.E., Beckman, C.W. 2002. Granivory. In: Herrera, C.M., Pellmyr, O. (Eds.) Plant-Animal Interactions. An Evolutionary Approach: 133-154 pp. Blackwell Publishing. UK.

Kelt, D.A., Meserve, P.L., Forister, M.L., Nabors, L.K., Gutiérrez, J.R. 2004. Seed predation by birds and small mammals in semiarid Chile. Oikos 104: 133-141.

Matthei, O. 1995. Manual de las Malezas que Crecen en Chile. Alfabeta Impresores, Santiago, Chile. 554 pp.

Moonen, A.C., Bàrberi, P. 2008. Functional biodiversity: An agroecosystem approach. Agriculture, Ecosystems and Environment 127: 7-21.

Muñóz, A.A., Arroyo, M.T.K. 2002. Post dispersal seed predation on Sisyrinchium arenarium (Iridaceae) at two elevations in the central Chilean Andes. Arctic, Antarctic, and Alpine Research 34: 178-184.

Muñóz, A.A., Cavieres, L.A. 2006. A multi-species assessment of post-dispersal seed predation in the central Chilean Andes. Annals of Botany-London 98: 193-201.

Navntoft, S., Wratten, S.D., Kristensen, K., Esbjerg, P. 2009.
Weed seed predation in organic and conventional fields. Biological Control 49: 11-16.

Sassi, P.L., Taraborelli, P.A., Borgui, C.E., Ojeda, R.A. 2006. The effect of grazing on granivory patterns in the temperate Monte Desert, Argentina. Acta Oecologica 29: 301-304.

Schäckermann, J., Pufal, G., Mandelik, Y., Klein, A.M. 2015. Agroecosystem services and dis-services in almond orchards are differentially influenced by the surrounding landscape. Ecological Entomology 40 (Suppl 1): 12-21.

Sekercioglu, C.H. 2007. Increasing awareness of avian ecological function. Trends in Ecology \& Evolution 21: 464-471.

Sekercioglu, C.H. 2012. Bird functional diversity and ecosystem services in tropical forest, agroforests, and agricultural areas. Journal of Ornithology 153 (Suppl 1): S153-S161.

Sieving, K.E., Willson, M.F., de Santo, T. 1996. Habitat barriers to movement of understory birds in fragmented southtemperate rainforest. Auk 113: 944-949.

Silva-Rodríguez, E.A., Ortega-Solíz, G.R., Jiménez, J.E. 2008. Descripción del ensamble de aves en un agroecosistema del sur de Chile. Boletín Chileno de Ornitología 14: 81-91.

Tews, J., Brose, U., Tielbörger, K., Wichmann, M.C., Schwager, M., Jeltsch, F. 2004. Animal species diversity driven by habitat heterogeneity/diversity: the importance of key stone structures. Journal of Biogeography 31: 79-92.

Tscharntke, T., Klein, A.M., Kruess, A., Steffan-Dewenter, I., Thies, C. 2005. Landscape perspectives on agricultural intensification and biodiversity - ecosystem services management. Ecology Letters 8: 857-874.

Van der Ree, R., Smith, D.J., Grilo, C. 2015. Handbook of Road Ecology. Wiley Blackwell, London, UK. 551 pp.

Van der Wall, S.B. 2010. How plants manipulate the scatterhoarding behaviour of seed-dispersing animals. Philosophical Translations of the Royal Society B 365: 989-997.

Vaz Ferreira, A., Bruna, E.M., Vasconcelos, H.L. 2011. Seed predators limit plant recruitment in Neotropical savannas. Oikos 120: 1013-1022.

Warzecha, B., Parker, V.T. 2014. Differential post-dispersal seed predation drives chaparral seed Banks dynamics. Plant Ecology 215: 1313-1322.

Westerman, P.R., Wes, J.S., Kropff, M.J., Van der Werf, W. 2003a. Annual losses of weed seed to predation in organic cereal fields. Journal of Applied Ecology 40: 824-836.

Westerman, P.R., Hofman, A., Vet, L.E.M., Van der Werf, W. 2003b. Relative importance of vertebrates and invertebrates in epigeaic weed seed predation in organic cereal fields. Agriculture, Ecosystems \& Environment 95: 417-425.

Worthy, F.R., Law, R., Hulme, P.E. 2006. Modelling the quantitative effects of pre- and post-dispersal seed predation in Pinus sylvestris L. Journal of Ecology 94: 1201-1213.

Zuria, I., Gates, J.E. 2013. Community composition, species richness, and abundance of birds in field margins of central Mexico: local and landscape-scale effects. Agroforestry Systems 87: 377-393. 